\title{
Wiesław Wasilewski
}

Uniwersytet Zielonogórski

e-mail: w.wasilewski@wez.uz.zgora.pl

\section{PLANOWANIE ARTYSTYCZNE W INSTYTUCJACH KULTURY}

\section{ARTISTIC PLANNING \\ IN CULTURAL INSTITUTIONS}

DOI: $10.15611 /$ pn.2017.471.38

JEL Classification: Z110

Streszczenie: Planowanie w instytucjach kultury wynika ze specyfiki prowadzonej działalności i często jest determinowane postawą dyrektora podmiotu. Celem artykułu jest przedstawienie i analiza planów działalności artystycznej instytucji kultury oraz określenie elementów charakterystycznych dla tego typu organizacji, na podstawie badań empirycznych i przeprowadzonych wywiadów oraz analizy literatury. Przedstawiona jest forma planów w układzie zadaniowym, która wydaje się być najbardziej korzystna z punktu widzenia samej organizacji oraz podmiotu założycielskiego.

Słowa kluczowe: controlling, planowanie, instytucje kultury.

Summary: Planning in cultural institutions is a result of the specific nature of business and is often determined by the attitude of a director of an entity. The aim of the paper is to analyze and present cultural activity plans of a cultural institution and to identify elements specific to this type of organizations, based on empirical research, interviews, and literature review. Plans are presented in the task system, which seems to be most favorable for the organization itself and the founding entity.

Keywords: controlling, planning, cultural institutions.

\section{Wstęp}

Planowanie artystyczne odgrywa kluczową rolę w zarządzaniu instytucją kultury, a jego zakres zależy od formy prowadzonej aktywności. Najszerszy jest w podmiotach prowadzących działalność estradową. Obejmuje planowanie finansowe sensu stricto, tak samo jak w przedsiębiorstwach komercyjnych. Należy jednak zwrócić uwagę, iż równie istotny jest tutaj także dodatkowy komponent - tworzenie planu sezonu artystycznego. To w nim zostaje ustalony repertuar, warunki angażu artystów 
gościnnych, zatrudnienia zespołu artystycznego oraz zarządzania obciążeniem sali koncertowej.

Planowanie artystyczne rozpoczyna się od sporządzenia planu finansowego przez księgowość instytucji i przedstawienia go organizatorowi, czyli podmiotowi, który finansuje działalność kulturalną. W planie tym ujęte są koszty i przychody związane z planowanymi wydarzeniami. Nie ma natomiast szczegółowych informacji na temat osób zaangażowanych do realizacji tych wydarzeń, miejsca oraz przewidywanego repertuaru. Te informacje przygotowuje dyrektor naczelny i artystyczny placówki na potrzeby wewnętrzne oraz rocznego sprawozdania merytorycznego. Tak przygotowany plan tworzy artystyczną mapę drogową instytucji.

\section{Instytucje kultury w Polsce}

Instytucje kultury są podstawowymi formami organizacyjnymi prowadzenia działalności kulturalnej w Polsce. Nazwa instytucja kultury jest zastrzeżona dla tych form organizacyjnych działalności kulturalnej, które działają na podstawie Ustawy z dnia 25 października 1991 r. o organizowaniu i prowadzeniu działalności kulturalnej (tekst jednolity Dz.U. z 2012 r., poz. 406 z późn. zm.), a ich założycielem jest minister lub kierownik urzędu centralnego (państwowe instytucje kultury) bądź samorząd terytorialny (samorządowe instytucje kultury). Organizator kultury, tworząc taki podmiot, wyposaża go $\mathrm{w}$ niezbędne mienie, które $\mathrm{z}$ chwilą wpisania jednostki do rejestru staje się mieniem nowego podmiotu prawa [Głowacki i in. 2009].

Instytucją kultury jest państwowa lub samorządowa osoba prawna, powołana w celu prowadzenia działalności kulturalnej. Do tego typu jednostek zalicza się przede wszystkim filharmonie i orkiestry, opery i operetki, teatry, muzea, galerie, kina, ośrodki, centra i domy kultury, biblioteki, instytucje ochrony i dokumentacji zabytków [Wróblewski 2012].

Ustawa o finansach publicznych zalicza państwowe i samorządowe instytucje kultury do jednostek sektora finansów publicznych. Placówka kultury z uzyskiwanych przychodów pokrywa koszty bieżącej działalności i zobowiązania. Są to wpływy z prowadzonej działalności, w tym ze sprzedaży składników majątku ruchomego, z wyjątkiem zabytków, oraz wpływy z najmu i dzierżawy składników majątkowych, dotacje z budżetu (państwa i samorządu), a także środki otrzymane od osób fizycznych i prawnych oraz z innych źródeł [Ustawa z 30 czerwca 2005].

Kwestia tego, jak zorganizowana jest rachunkowość w instytucjach kultury oraz jak szczegółowo prowadzona jest w nich ewidencja księgowa, zależy od tego, czy instytucja uznana jest za małą, czy dużą. Małe instytucje sporządzają uproszczone sprawozdanie finansowe, natomiast duże mają obowiązek sporządzania pełnego sprawozdania finansowego, które podlega następnie badaniu przez biegłego rewidenta. Dużą instytucją jest taka, która w roku obrotowym poprzedzającym sprawozdanie finansowe spełniła co najmniej dwa z następujących warunków [Ustawa z 29 września 1994]:

- średnioroczne zatrudnienie w przeliczeniu na pełne etaty wyniosło co najmniej 50 osób, 
- suma aktywów bilansu na koniec roku obrotowego stanowiła równowartość w walucie polskiej co najmniej $2 \mathrm{mln}$ euro,

- przychody netto ze sprzedaży towarów i produktów oraz operacji finansowych za rok obrotowy stanowiły równowartość w walucie polskiej co najmniej $4 \mathrm{mln}$ euro.

Instytucje kultury, które prowadzą działalność gospodarczą i otrzymują znaczące wsparcie prowadzonej działalności kulturalnej w formie dotacji, są zgodnie z przepisami przedsiębiorcami publicznymi [Ustawa z 22 września 2006]. Przedsiębiorcą publicznym jest każdy podmiot prowadzący działalność gospodarczą, bez względu na sposób działania oraz formę organizacyjno-prawną, na którego działalność wywiera decydujący wpływ organ publiczny. Organem publicznym są w tym przypadku organy administracji rządowej (ministrowie i kierownicy urzędów centralnych) oraz organy jednostek samorządu terytorialnego [Wieczorek 2011]. Tabela 1 przedstawia źródła finansowania działalności instytucji kultury.

Tabela 1. Wady i zalety różnych źródeł finansowania instytucji kultury

\begin{tabular}{|l|l|l|}
\hline \multicolumn{1}{|c|}{ Źródła finansowania } & \multicolumn{1}{|c|}{ Wady } & \multicolumn{1}{c|}{ Zalety } \\
\hline $\begin{array}{l}\text { Dotacje lub subwencje } \\
\text { z budżetu państwa i budżetów } \\
\text { jednostek samorządu } \\
\text { terytorialnego }\end{array}$ & $\begin{array}{l}\text { w długim terminie nie można } \\
\text { przewidzieć i zagwarantować stałości }\end{array}$ & $\begin{array}{l}\text { relatywnie łatwe } \\
\text { w pozyskaniu oraz } \\
\text { utrzymaniu; } \\
\text { znaczny udział procentowy }\end{array}$ \\
\hline $\begin{array}{l}\text { Mecenasi sztuki i instytucje } \\
\text { finansujące }\end{array}$ & $\begin{array}{l}\text { trudne w pozyskaniu przy braku } \\
\text { odpowiedniego know-how; } \\
\text { zależne od bliskości geograficznej } \\
\text { i zaangażowania podmiotu }\end{array}$ & $\begin{array}{l}\text { efekt synergii; } \\
\text { współpraca w obszarach } \\
\text { pozafinansowych }\end{array}$ \\
\hline Fundraising & $\begin{array}{l}\text { potrzebny wyszkolony personel; } \\
\text { niska efektywność }\end{array}$ & $\begin{array}{l}\text { małe nakłady finansowe } \\
\text { związane z wdrożeniem } \\
\text { fundraisingu }\end{array}$ \\
\hline Sponsoring & $\begin{array}{l}\text { w zależności od zawartej umowy } \\
\text { mogą wystąpić duże nakłady } \\
\text { czasowe oraz konieczność } \\
\text { dostosowania się do sponsora }\end{array}$ & $\begin{array}{l}\text { jasne warunki współpracy; } \\
\text { wysoki udział procentowy }\end{array}$ \\
\hline $\begin{array}{l}\text { Przychody z własnej } \\
\text { działalności (utarg ze sprzedaży } \\
\text { biletów, odnajmowanie } \\
\text { pomieszczeń itp.) }\end{array}$ & $\begin{array}{l}\text { zależne od własnej efektywności; } \\
\text { czasochłonne }\end{array}$ & $\begin{array}{l}\text { zależne od własnej } \\
\text { efektywności; } \\
\text { brak nacisków ze strony } \\
\text { sponsora }\end{array}$ \\
\hline $\begin{array}{l}\text { Środki z funduszy } \\
\text { zagranicznych, w tym } \\
\text { zwłaszcza unii europejskiej }\end{array}$ & $\begin{array}{l}\text { wymagana fachowa wiedza; } \\
\text { czasochłonne }\end{array}$ & wysoki udział procentowy \\
\hline
\end{tabular}

Źródło: opracowanie własne.

Podstawą gospodarki finansowej instytucji kultury jest ,plan finansowy ustalony przez dyrektora, z zachowaniem wysokości dotacji organizatora" [Ustawa 
z 25 października 1991]. Sporządzony zgodnie z zapisami ustawy o finansach publicznych, powinien uwzględniać plan usług i przychodów z prowadzonej działalności, wielkość dotacji, plan kosztów (w tym wynagrodzenia i pochodne od wynagrodzeń, koszty zakupu towarów i usług, inne płatności wynikające z zaciągniętych zobowiązań), wydatki majątkowe (plan kosztów ewentualnych remontów, konserwacji oraz inwestycji - zależnie od potrzeb), a także stan należności i zobowiązań na początek i koniec roku oraz stan środków pieniężnych na początek i koniec roku [Ustawa z 27 sierpnia 2009].

Dofinansowanie organizatora może mieć formę dotacji podmiotowej, która jest przeznaczona na dofinansowanie działalności bieżącej w zakresie realizowanych zadań statutowych, w tym na utrzymanie i remonty obiektów, oraz dotacji celowejna finansowanie lub dofinansowanie kosztów realizacji inwestycji lub na realizację wskazanych zadań i programów [Ustawa z 25 października 1991]. Dotacja podmiotowa jest przekazywana instytucji co miesiąc jako 1/12 wartości ogółu rocznej dotacji, zgodnie z opracowanym przez organizatora harmonogramem realizacji budżetu.

Środki przekazywane przez organizatorów instytucjom kultury stanowią szczególną kategorię - są to tzw. środki publiczne [Ustawa z 27 sierpnia 2009]. Osoby zarządzające mieniem i środkami publicznymi muszą czynić to ze szczególną starannością, uwzględniając wiele związanych z tym zasad i procedur, z założenia mających na celu podnoszenie efektywności oraz ekonomiki ich wykorzystania [Wasilewski 2015]. Niegospodarność w zarządzaniu środkami publicznymi wiąże się z naruszeniem dyscypliny finansów publicznych [Ustawa z 17 grudnia 2004]. Może się to stać poprzez m.in. doprowadzenie do uszczuplenia wpływów należnych instytucji, przekroczenie kwoty planowanych wydatków, ustalonej w planie finansowym, niezrealizowanie zobowiązań mimo upływu terminu płatności lub udzielenie zamówienia publicznego wykonawcy, który nie został wyłoniony w trybie przetargu, mimo iż tryb taki należało zastosować [Szulborska-Łukaszewicz 2012].

W odróżnieniu do krajów Europy Zachodniej, dominującym źródłem finansowania instytucji kultury w Polsce cały czas są środki budżetowe w postaci dotacji organizatora oraz Ministerstwa Kultury. Stąd też wynika szczególna rola państwa w kontrolowaniu zasadności ich wydatkowania.

\section{Podstawy sporządzania planów w instytucjach kultury}

Planowanie w instytucji kultury obejmuje kilka poziomów funkcjonowania podmiotu. Menedżer skupia swoją uwagę na planowaniu wykorzystania sali, frekwencji widowni oraz pracy zespołu artystycznego. Na tej pracy, ale pod kątem repertuaru koncentruje się dyrektor artystyczny. Księgowość oraz dyrektor naczelny przygotowują dokumenty wymagane przez organizatora, przede wszystkim plan finansowy wraz z przychodami i kosztami.

Rysunek 1 przedstawia fragment terminarza pracy orkiestry Scottish National Orchestra w sezonie 2012-2013. Zawiera termin, miejsce i rodzaj wydarzenia, wymagany skład zespołu oraz nazwiska dyrygenta i solistów. 


\begin{tabular}{|c|c|c|c|c|c|c|c|c|}
\hline$\Delta$ & A & B & C & D & E & $\mathrm{F}$ & G & \\
\hline 1 & 2012:13 & & & & & & & as at 9-May-2012 \\
\hline 11 & & & & & & & & \\
\hline 12 & Week begins & Date & \multicolumn{2}{|c|}{$\underline{\text { Venue }}$} & BBC & $\underline{\mathrm{SCO}}$ & & Conductor(s) \\
\hline 113 & \multirow[t]{7}{*}{29 Oct 12} & Thr 1 & $\mathrm{P}$ & & & & \multirow{7}{*}{$\begin{array}{l}\text { Maestro Music I } \\
\text { Children's Classics } 1\end{array}$} & Christian Kluxen \\
\hline 114 & & & D & 2nd p & & $\mathrm{T}$ & & \\
\hline 115 & & & A & $\mathrm{Y}$ & & 0 & & PO Cincinnati Sym \\
\hline 116 & & & 1 & $\mathrm{~N}$ & & $\mathrm{U}$ & & n/a: Andrew Davis \\
\hline 117 & & & G & $\mathrm{Y}$ & G & $\mathrm{R}$ & & avail: Slobodeniouk \\
\hline 118 & & Fri 2 & $\mathrm{E}$ & r & 1 & & & \\
\hline 119 & & Sat 3 & G & Y & & & & \\
\hline 120 & \multirow[t]{7}{*}{5 Nov 12} & Thr 8 & $\mathrm{P}$ & & & & \multirow[t]{7}{*}{ Season 4} & Oundjian 3 \\
\hline 121 & & & D & & & $\mathrm{T}$ & & \\
\hline 122 & & & A & Y (A2?) & & 0 & & PO pencilled \\
\hline 123 & & & 1 & $\mathrm{~N}$ & & $\mathrm{U}$ & & \\
\hline 124 & & & G & Y & G & $\mathrm{R}$ & & \\
\hline 125 & & Fri 9 & E & Y & & & & \\
\hline 126 & & Sat 10 & G & Y & $11 \mathrm{E}$ & & & \\
\hline 127 & \multirow[t]{7}{*}{12 Nov 12} & Thr 15 & $\mathrm{P}$ & & & & \multirow[t]{7}{*}{ Naked Classics 1} & \multirow{7}{*}{$\begin{array}{l}\text { Thomas Sønderg } \\
\text { PO: Toronto } \\
\text { Andrew Davis n/a } \\
\text { avail: Slobodeniouk } \\
\text { Neeme Jarvi was p } \\
\text { Neeme in States p } \\
\text { probably n/a: Sond }\end{array}$} \\
\hline 128 & & & D & Y & & & & \\
\hline 129 & & & A & Y & & & & \\
\hline 130 & & & I & $\mathrm{N}$ & & & & \\
\hline 131 & & & G & $r$ & G & & & \\
\hline 132 & & Fri 16 & $\mathrm{E}$ & Y & $\mathrm{A} !$ & & & \\
\hline 133 & & Sat 17 & G & Y & & $\mathrm{P}$ & & \\
\hline 134 & \multirow[t]{3}{*}{19 Nov 12} & Thr 22 & $\mathrm{P}$ & & & & \multirow[t]{3}{*}{ Season 5} & Kazushi Ono \\
\hline 135 & & & D & & & & & \\
\hline 136 & & & A & Y & & 0 & & \\
\hline $\begin{array}{l}127 \\
144\end{array}$ & n & & $6-0$ & & & 5 & & $2011-12$ \\
\hline
\end{tabular}

Rys. 1. Terminarz pracy Scottish National Orchestra

Źródło: [Mahood 2012].

\begin{tabular}{|c|c|c|c|c|c|}
\hline 4 & A & B & D & $\mathrm{E}$ & $\mathrm{F}$ \\
\hline 3 & Repertoire & & $\underline{\text { RSNO }}$ & BBC SSO & $\underline{\mathrm{SCO}}$ \\
\hline 4 & Adams & Doctor Atomic Symphony & Apr-13 & & \\
\hline 5 & Adams & Harmonielehre & Feb-13 & & \\
\hline 6 & Adès & Dances from Powder Her Face & Nov-12 & & \\
\hline 7 & Andersson & The Garden of Delights & Oct-12 & & \\
\hline 8 & Andre & $\mathrm{Hij}$ & & Oct-12 & \\
\hline 9 & Arensky & Variations on a Theme of Tchaikovsky & Mar-13 & & \\
\hline 10 & Bacewitz & Concerto for String Orchestra & & Oct-12 & \\
\hline 11 & Bach & Brandenburg TBC & & May-13 & \\
\hline 12 & Bach/arr. Webern & Ricercar from The Musical offering & & & Mar-13 \\
\hline 13 & Barber & Cello Concerto & & & Oct-12 \\
\hline 14 & Barber & Piano Concerto & Apr-13 & & \\
\hline 15 & Bartók & Dance Suite & & Dec-12 & \\
\hline 16 & Bartók & Miraculous Mandarin Suite & & Dec-12 & \\
\hline 17 & Bartók & Piano Concerto No. 1 & & Dec-12 & \\
\hline 18 & Bartók & Piano Concerto No. 2 & & Dec-12 & \\
\hline 19 & Bartók & Piano Concerto No. 3 & & Dec-12 & \\
\hline 20 & Beethoven & Grosse Fuge & & & Apr-13 \\
\hline 21 & Beethoven & Leonore Overture No. 3 & Mar-13 & & \\
\hline 22 & Beethoven & Piano Concerto No. 2 & & & Dec-12 \\
\hline 23 & Beethoven & Piano Concerto No. 3 & Mar-13 & & \\
\hline 24 & Beethoven & Piano Concerto No. 4 & & Oct-12 & \\
\hline 25 & Beethoven & Piano Concerto No. 5 & & May-13 & \\
\hline
\end{tabular}

Rys. 2. Repertuar koncertowy z terminami i przydziałem zespołu wykonawczego Źródło: [Mahood 2012]. 
Rysunek 2 przedstawia fragment repertuaru koncertowego z terminami wykonania poszczególnych utworów oraz zaangażowanym w tym celu składem zespołu. Może to być Szkocka Narodowa Orkiestra Symfoniczna, Radiowa Szkocka Orkiestra Symfoniczna BBC lub Szkocka Orkiestra Kameralna. Decydujący tutaj będzie profil danej orkiestry oraz wymagany skład instrumentów do danego programu.

Syntetyczny plan roczny orkiestry szkockiej, obejmujący dwa największe miasta Glasgow oraz Edynburg, wygląda następująco:

- 18 koncertów sezonowych,

- 3 koncerty specjalne z cyklu Naked Classics (z efektami wizualnymi oraz wywiadami na żywo),

- 2 tygodnie koncertów szkolnych,

- 2 tygodnie koncertów świątecznych,

- 3 koncerty kameralne,

- 2 koncerty dla dzieci,

- 4 tygodnie koncertów festiwalowych,

- około 30 koncertów wyjazdowych.

Można to porównać z programem innego zespołu z Wysp Brytyjskich. City of London Sinfonia planuje swoją roczną aktywność artystyczną na poziomie:

- 113 koncertów,

- 51 dni prób,

- 4 sesje nagraniowe,

- 90 dni pracy edukacyjnej,

- 1 tournée zagraniczne.

W celu realizacji tych aktywności zaplanowano w zł:

Przychody:

- Własne (np. sprzedaż biletów, wynajem sali etc.): 4.800 .000

- Fundraising: 3.200 .000

- Razem: 8.000.000

Wydatki:

- Koszty zarządu: 2.700 .000

- Koszty działań artystycznych: 5.300 .000

- Razem: 8.000.000

Przedstawiony przykład Scottish National Orchestra oraz City of London Sinfonia obrazuje fragment stosowanej w Wielkiej Brytanii dokumentacji związanej z planowaniem działalności artystycznej wraz z kalkulacją kosztów i przychodów. Można zauważyć szczególną wagę zarządzania zespołem artystycznym. Każdy zatrudniony artysta i pracownik obsługi jest poinformowany z wyprzedzeniem o kolejnym miejscu swojej pracy oraz wykonywanym repertuarze.

Zgodnie z ustawą o rachunkowości oraz wymogami podmiotów założycielskich i nadzorujących każda instytucja kultury w Polsce jest zobowiązana do prowadzenia odpowiedniej dokumentacji [Wróblewski 2012]. Dokumenty związane z planowaniem to plan działalności oraz plan finansowy: 
1. Plan działalności instytucji:

- plan usług,

- plan przychodów i kosztów,

- plan remontów,

- plan inwestycji,

- plan dofinansowań.

2. Plan finansowy:

- przychody z prowadzonej działalności,

- dotacje,

- koszty (wynagrodzenia, zakup towarów i usług itp.),

- środki na wydatki majątkowe,

- środki przyznane innym podmiotom,

- stan należności i zobowiązań na początek i koniec okresu sprawozdawczego.

Wszystkie sporządzane plany muszą uwzględniać dotację. Organizator może nakazać sporządzanie planów tradycyjnie lub w układzie zadaniowym. Panuje tutaj dowolność związana z tym, iż przepisy nie określają szczegółowo zasad sporządzania planów. Istotne jest, aby zawierały one zestawienie kosztów i przychodów finansujących te koszty. Dyrektor instytucji zatwierdza plan finansowy, i tylko on jest uprawniony do zatwierdzania zmian i korekt.

Tabela 2. Wzór planu działalności merytorycznej instytucji kultury

\begin{tabular}{|c|c|c|c|c|c|}
\hline \multirow{2}{*}{$\begin{array}{c}\text { Rodzaj } \\
\text { działalności }\end{array}$} & \multicolumn{5}{|c|}{ Plan finansowy na rok ...-część finansowo-merytoryczna } \\
\cline { 2 - 6 } & Plan na dzień... & Liczba & $\begin{array}{c}\text { Liczba } \\
\text { słuchaczy }\end{array}$ & Frekwencja \% & Część opisowa \\
\hline 1 & 2 & 3 & 4 & 5 & 6 \\
\hline & & & & & \\
\hline
\end{tabular}

Źródło: opracowanie własne na podstawie wywiadów przeprowadzonych w instytucjach kultury.

Plan działalności merytorycznej przedstawia przede wszystkim wydarzenia artystyczne wraz z planowaną frekwencją odbiorców. Dołącza się także opis poszczególnych wydarzeń wraz ze szczegółowym repertuarem.

Plan przychodów i kosztów uwzględnia przede wszystkim przychody własne (z prowadzonej działalności) oraz wszelkie dotacje (z budżetu Miasta, Województwa oraz Ministerstwa Kultury). Natomiast po stronie kosztów wynagrodzenia, amortyzację, usługi obce, podatki i opłaty etc. W zestawieniu tym ujęte są również w miarę potrzeb środki na remonty oraz na działalność inwestycyjną.

Plan remontów i konserwacji środków trwałych jest sporządzany, gdy taka potrzeba w danym roku występuje. Koszty pokrywane są z dotacji podmiotowej organizatora, dotacji celowej Ministerstwa Kultury lub środków własnych. Są one ujęte w planie przychodów i kosztów. Plan inwestycyjny jest sporządzany, gdy instytucja planuje zadania i zakupy inwestycyjne, których wartość przekracza 3500 zł. [Pietrzak 2011]. 
Tabela 3. Plan przychodów i kosztów instytucji kultury

\begin{tabular}{|c|l|}
\hline Lp. & \multicolumn{1}{|c|}{ Wyszczególnienie } \\
\hline 1 & \\
\hline I. & Przychody ogólem \\
\hline $\mathbf{1 .}$ & Przychody własne \\
\hline & przychody z prowadzonej działalności \\
\hline & sprzedaż składników majątku ruchomego \\
\hline & najem i dzierżawa składników majątkowych \\
\hline & pozostałe przychody własne \\
\hline $\mathbf{2 .}$ & Dotacja budżetu Miasta na działalność bieżącą \\
\hline $\mathbf{3 .}$ & Dotacja z budżetu Województwa na działalność bieżacą \\
\hline $\mathbf{4 .}$ & Środki otrzymane bezpośrednio przez Instytucję \\
\hline & środki finansowe Ministra Kultury \\
\hline & środki z funduszy międzynarodowych \\
\hline & VAT podlegający zwrotowi (-) \\
\hline $\mathbf{5 .}$ & Środki finansowe otrzymane od osób fizycznych i prawnych \\
\hline $\mathbf{6 .}$ & Przychody finansowe \\
\hline $\mathbf{7 .}$ & Inne źródła \\
\hline II. & Koszty ogółem \\
\hline $\mathbf{1 .}$ & Koszty wg rodzaju \\
\hline & amortyzacja \\
\hline & zużycie materiałów i energii \\
\hline & usługi obce \\
\hline & remonty \\
\hline & transport \\
\hline & pozostałe usługi \\
\hline & podatki i opłaty \\
\hline & podatek od nieruchomości \\
\hline & podatek od śr. transportowych \\
\hline & ubezpieczenia majątkowe \\
\hline & podatek VAT \\
\hline & PFRON \\
\hline & tantiemy \\
\hline & pozostałe \\
\hline & hynagrodzenia \\
\hline & \\
\hline & \\
\hline &
\end{tabular}




\begin{tabular}{|c|l|}
\hline 1 & \multicolumn{1}{|c|}{2} \\
\hline & wynagrodzenia bezosobowe, prowizje \\
\hline & ubezpieczenia społeczne i inne świadczenia \\
\hline & składki naliczane od wynagrodzeń \\
\hline & Zakładowy Fundusz Świadczeń Socjalnych \\
\hline & pozostałe \\
\hline & inne koszty rodzajowe \\
\hline & podróże służbowe \\
\hline & pozostałe \\
\hline & wartość sprzedanych towarów i materiałów \\
\hline $\mathbf{2 .}$ & Pozostałe koszty operacyjne \\
\hline $\mathbf{3}$. & Koszty finansowe \\
\hline & płatności odsetkowe wynikające z zaciągniętych zobowiązań \\
\hline & pozostałe koszty finansowe \\
\hline
\end{tabular}

Źródło: opracowanie własne na podstawie wywiadów przeprowadzonych w instytucjach kultury.

Tabela 4. Plan inwestycyjny

\begin{tabular}{|l|l|}
\hline VII. & Środki na działalność inwestycyjną \\
\hline $\mathbf{1 .}$ & Dotacja z budżetu Miasta \\
\hline & Środki własne Miasta \\
\hline & środki finansowe Ministra Kultury \\
\hline & środki z funduszy międzynarodowych \\
\hline & VAT podlegający zwrotowi (-) \\
\hline $\mathbf{2 .}$ & Dotacja z budżetu Województwa \\
\hline & środki własne Województwa \\
\hline & Środki finansowe Ministra Kultury \\
\hline & Środki z funduszy międzynarodowych \\
\hline & VAT podlegający zwrotowi (-) \\
\hline $\mathbf{3 .}$ & Środki otrzymane bezpośrednio przez Instytucję \\
\hline & Środki finansowe Ministra Kultury \\
\hline & środki z funduszy międzynarodowych \\
\hline & VAT podlegający zwrotowi (-) \\
\hline
\end{tabular}

Źródło: opracowanie własne na podstawie wywiadów przeprowadzonych w instytucjach kultury.

Oprócz ustawy o organizowaniu i prowadzeniu działalności kulturalnej zastosowanie mają tutaj również ustawa o finansach publicznych, która nakazuje ujęcie wydatków w planie finansowym, oraz ustawa o dyscyplinie środków publicznych, która 
reguluje kwestie związane z naruszeniem dyscypliny finansów publicznych. Plan zawiera opis i cel zadania oraz podaje źródło finansowania (najczęściej dotacja organizatora, dotacja celowa Ministerstwa Kultury lub środki własne).

U. Pietrzak proponuje, aby plan bieżącej działalności tworzyć w układzie zadaniowym według zasad Ministerstwa Kultury [Pietrzak 2011]. Otrzymuje się wtedy plan w kilku częściach, bardziej szczegółowy i oferujący więcej informacji dla rewidenta.

Tabela 5. Plan działalności bieżącej w układzie zadaniowym

\begin{tabular}{|c|c|c|c|c|}
\hline Lp. & Nazwa zadania & $\begin{array}{c}\text { Specyfikacja } \\
\text { działań } \\
\text { podejmowanych } \\
\text { w celu realizacji } \\
\text { zadania }\end{array}$ & Cel realizacji & Opis miernika \\
\hline 1 & 2 & 3 & 4 & 5 \\
\hline 1 & Premiery & & $\begin{array}{l}\text { zapoznanie społeczeństwa } \\
\text { z dorobkiem kulturalnym }\end{array}$ & $\begin{array}{l}\text { liczba premier/liczba } \\
\text { uczestników }\end{array}$ \\
\hline 2 & $\begin{array}{l}\text { Wystawianie } \\
\text { spektakli/ koncertów } \\
\text { itp. }\end{array}$ & & $\begin{array}{l}\text { zapoznanie społeczeństwa } \\
\text { z dorobkiem kulturalnym }\end{array}$ & $\begin{array}{l}\text { liczba spektakli/liczba } \\
\text { widzów }\end{array}$ \\
\hline $2 \mathrm{a}$ & $\begin{array}{l}\text { Koszty organizacji } \\
\text { widowni }\end{array}$ & & działalność pomocnicza & \\
\hline $2 \mathrm{~b}$ & $\begin{array}{l}\text { Promocja i reklama } \\
\text { spektakli }\end{array}$ & $\begin{array}{l}\text { druk repertuaru, } \\
\text { plakatów, } \\
\text { kalendarza } \\
\text { imprez itp. }\end{array}$ & działalność pomocnicza & \\
\hline $2 \mathrm{c}$ & Obsługa sceny & & działalność pomocnicza & \\
\hline $2 \mathrm{f}$ & $\begin{array}{l}\text { Zakup wyposażenia } \\
\text { i amortyzacja }\end{array}$ & & $\begin{array}{l}\text { koszty pośrednie } \\
\text { działalności }\end{array}$ & \\
\hline $2 g$ & $\begin{array}{l}\text { Koszty zatrudnienia } \\
\text { pracowników }\end{array}$ & & $\begin{array}{l}\text { koszty pośrednie } \\
\text { działalności }\end{array}$ & $\begin{array}{l}\text { liczba etatów/ w tym } \\
\text { artystycznych }\end{array}$ \\
\hline $2 \mathrm{~h}$ & $\begin{array}{l}\text { Koszty utrzymania } \\
\text { obiektów }\end{array}$ & & $\begin{array}{l}\text { koszty pośrednie } \\
\text { działalności }\end{array}$ & $\begin{array}{l}\text { liczba obiektów/pow. } \\
\mathrm{w} \mathrm{m}^{2}\end{array}$ \\
\hline $2 \mathrm{i}$ & Koszty ogólne & & $\begin{array}{l}\text { koszty pośrednie } \\
\text { działalności }\end{array}$ & \\
\hline 3 & $\begin{array}{l}\text { Spektakle/ koncerty/ } \\
\text { występy wyjazdowe }\end{array}$ & & $\begin{array}{l}\text { rozwój kulturalny } \\
\text { społeczeństwa, zapoznanie } \\
\text { z dorobkiem kultury }\end{array}$ & $\begin{array}{l}\text { liczba imprez/liczba } \\
\text { uczestników }\end{array}$ \\
\hline
\end{tabular}

Źródło: opracowanie własne na podstawie [Pietrzak 2011].

Zadania są przyporządkowane planowi Ministerstwa Kultury. Oprócz celu zadania występuje miernik oceny realizacji wyznaczonego celu, koszt realizacji oraz źródło finansowania. Plan remontów w układzie zadaniowym przedstawia tabela 6 . 
Tabela 6. Plan remontów w układzie zadaniowym

\begin{tabular}{|c|c|c|c|}
\hline Lp. & Opis zadania & Cel realizacji & Opis miernika \\
\hline 1 & 2 & 3 & 4 \\
\hline 1 & $\begin{array}{l}\text { Prace konserwatorskie i restauratorskie związane } \\
\text { z poprawą stanu zachowania ruchomych obiektów } \\
\text { zabytkowych wpisanych do rejestru zabytków }\end{array}$ & $\begin{array}{l}\text { zabezpieczenie dorobku } \\
\text { kultury }\end{array}$ & liczba ob. \\
\hline 2 & $\begin{array}{l}\text { Konserwacja, zabezpieczanie } \\
\text { i digitalizacja muzealiów(w tym zbiorów sztuki) }\end{array}$ & $\begin{array}{l}\text { zabezpieczenie dorobku } \\
\text { kultury }\end{array}$ & \\
\hline 3 & Prace konserwatorskie i restauratorskie ... & $\begin{array}{l}\text { poprawa jakości } \\
\text { świadczenia usług }\end{array}$ & $\begin{array}{l}\text { liczba ob./ pow } \\
\mathrm{w} \mathrm{m}^{2}\end{array}$ \\
\hline 4 & Konserwacja zbiorów bibliotecznych & $\begin{array}{l}\text { poprawa jakości } \\
\text { świadczenia usług }\end{array}$ & ilość ob. \\
\hline 5 & Remont obiektów niezabytkowych & $\begin{array}{l}\text { poprawa jakości } \\
\text { świadczenia usług }\end{array}$ & $\begin{array}{l}\text { liczba ob./ pow. } \\
\mathrm{w} \mathrm{m}^{2}\end{array}$ \\
\hline 6 & Kapitalny remont urządzeń & $\begin{array}{l}\text { poprawa jakości } \\
\text { świadczenia usług }\end{array}$ & \\
\hline
\end{tabular}

Źródło: opracowanie własne na podstawie [Pietrzak 2011].

W planie remontów obok celu zadania ujęty jest także miernik oraz jego odchylenie plan-wykonanie. Istotne jest podanie źródła finansowania wraz z terminem zakończenia zadania oraz nazwiskiem osoby odpowiedzialnej. Plan inwestycyjny w układzie zadaniowym przedstawia tabela 7 .

Tabela 7. Plan inwestycyjny w układzie zadaniowym

\begin{tabular}{|c|c|c|c|}
\hline Lp. & Opis zadania & Cel realizacji & Opis miernika \\
\hline 1 & 2 & 3 & 4 \\
\hline 1 & $\begin{array}{l}\text { Realizacja inwestycji } \\
\text { w obiektach zabytkowych }\end{array}$ & $\begin{array}{l}\text { zabezpieczenie dorobku } \\
\text { kultury }\end{array}$ & $\begin{array}{l}\text { liczba ob./pow. } \\
\mathrm{w} \mathrm{m}^{2}\end{array}$ \\
\hline 2 & $\begin{array}{l}\text { Realizacja inwestycji } \\
\text { w obiektach niezabytkowych }\end{array}$ & $\begin{array}{l}\text { poprawa jakości świadczenia } \\
\text { usług }\end{array}$ & $\begin{array}{l}\text { liczba ob./pow. } \\
\mathrm{w} \mathrm{m}^{2}\end{array}$ \\
\hline 3 & $\begin{array}{l}\text { Zakupy inwestycyjne środków trwałych } \\
\text { i oprogramowania pow. } 3500\end{array}$ & $\begin{array}{l}\text { poprawa jakości świadczenia } \\
\text { usług }\end{array}$ & \\
\hline 4 & Organizacja wystaw stałych & $\begin{array}{l}\text { poprawa jakości udostępniania } \\
\text { zbiorów muzealnych }\end{array}$ & \\
\hline 5 & Odzyskiwanie utraconych obiektów & powiększenie zbiorów & $\begin{array}{l}\text { liczba odzyskanych } \\
\text { obiektów }\end{array}$ \\
\hline 6 & Zakup muzealiów & powiększenie zbiorów & liczba obiektów \\
\hline 7 & $\begin{array}{l}\text { Stworzenie jednolitego ogólnopolskiego } \\
\text { centralnego systemu komputerowego }\end{array}$ & $\begin{array}{l}\text { poprawa jakości świadczenia } \\
\text { usług }\end{array}$ & \\
\hline 8 & $\begin{array}{l}\text { Adaptacja dla ułatwienia dostępu dla } \\
\text { niepełnosprawnych }\end{array}$ & $\begin{array}{l}\text { poprawa jakości świadczenia } \\
\text { usług }\end{array}$ & \\
\hline
\end{tabular}

Źródło: opracowanie własne na podstawie [Pietrzak 2011]. 
Podobnie prezentuje się plan inwestycyjny w układzie zadaniowym. Konstrukcja wszystkich powyższych planów umożliwia przyporządkowanie kosztów do poszczególnych zadań. Jest to istotne nie tylko z punktu widzenia jednostkowej instytucji, ale również jej organizatora, który dąży do ujednolicenia dokumentacji otrzymywanej od podległych mu jednostek.

\section{Zakończenie}

Zaliczanie kosztów stałych do zadania głównego w budżecie zadaniowym niesie ze sobą wiele korzyści. Łatwiej jest planować koszty bezpośrednie zadań oraz koszty stałe. Można szybciej sporządzać sprawozdania. Umożliwia analizę i prognozowanie kosztów bezpośrednich i pośrednich w jednostce w dłuższych okresach, co przy planowaniu wieloletnim ma istotne znaczenie. Instytucja może wypracować najbardziej wiarygodny klucz podziału do rozliczania kosztów pośrednich. Organizator otrzymuje możliwość lepszego porównywania kosztów realizowanych zadań między różnymi instytucjami artystycznymi oraz planowania zastosowania jednolitego klucza podziału kosztów bezpośrednich na zadania na podstawie otrzymanych informacji z podległych jednostek. Analiza porównawcza zamierzeń do rzeczywistości dostarcza kierownictwu danych dotyczących planu i przebiegu jego realizacji jako elementu kontroli działalności.

\section{Literatura}

Głowacki J., Hausner J., Jakóbik K., Markiel K., Mituś A., Żabiński M., 2009, Finansowanie kultury i zarządzanie instytucjami kultury, UE w Krakowie, Kraków.

Mahood G., 2012, Royal Scottish National Orchestra Venue and Programme Coordination, Materiał konferencyjny „Zarządzanie Muzycznymi Instytucjami Kultury”, Szczecin.

Pietrzak U., 2011, Budzet zadaniowy $i$ wydatki strukturalne w instytucjach kultury, ODDK, Gdańsk.

Szulborska-Łukaszewicz J., 2012, Instytucje kultury w Polsce specyfika ich organizacji i finansowania, Zarządzanie w Kulturze, nr 13, z. 4.

Ustawa z dnia 25 października 1991 r. o organizowaniu i prowadzeniu działalności kulturalnej, tekst jednolity Dz.U. z 2012 r., poz. 406 z późn. zm.

Ustawa z dnia 29 września 1994 r. o rachunkowości, Dz.U. z 2009 r., nr 152, poz. 1223 z późn. zm.

Ustawa z 17 grudnia 2004 r. o odpowiedzialności za naruszenie dyscypliny finansów publicznych, Dz.U. z 2005 r., nr 14, poz. 114, nr 249, poz. 2104 z późn. zm.

Ustawa z dnia 27 sierpnia 2009 r. o finansach publicznych, Dz.U. z 2009 r., nr 157, poz. 1240.

Ustawa z dnia 22 września 2006 r. o przejrzystości stosunków finansowych pomiędzy organami publicznymi a przedsiębiorcami publicznymi oraz o przejrzystości finansowej niektórych przedsiębiorców, Dz.U. z 2006 r., nr 191, poz. 1411 z późn. Zm.

Wasilewski W., 2015, Controlling ryzyka w instytucjach kultury, Prace Naukowe Uniwersytetu Ekonomicznego we Wrocławiu, nr 399.

Wieczorek P., 2011, Instytucje kultury. Rachunkowość, sprawozdawczość, gospodarka finansowa, kontrola zarzadcza, C.H. Beck, Warszawa.

Wróblewski Ł., 2012, Strategie marketingowe w instytucjach kultury, PWE, Warszawa. 